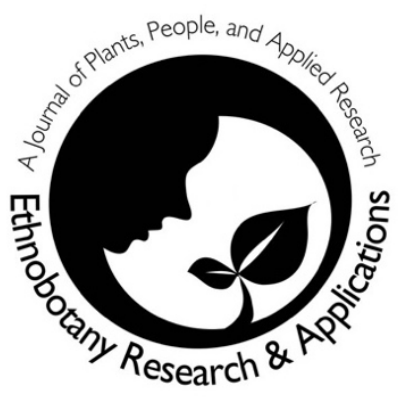

\title{
Ethnobotany of Elaeis guineensis Jacq. and its importance in the household economy of the Ikale and llaje of Ondo State, Nigeria
}

\author{
Sakiru Morenikeji Erinoso, David Olaniran Aworinde, \\ Olasimbo Anuoluwapo Teniola and Samuel Omoniyi Ojo
}

\section{Research}

\begin{abstract}
Background: African oil palm (Elaeis guineensis Jacq.), a perennial crop that originated from Tropical rainforest of West Africa, is one of the most important economic oil crops in Nigeria providing income for rural and semi-urban folks. This study described the ethnobotany of the plant and evaluated the extent to which it contributes to the livelihood strategies of the Ikale and Ilaje speaking people of Ondo State, Nigeria.
\end{abstract}

Methods: Interviews were conducted in the local language and questionnaires were administered to willing respondents. Photographs of tools/machines used in the production of palm oil and allied products were taken. Drawings of the tools were generated on site.

Results: The plant is the principal source of palm oil. Major processing tools of palm oil include cracker, presser, digester, and boiling trough. Other products that are derived from oil palm parts are palm kernel oil, kernel meat (for livestock feed), kernel shells (for fuel), palm wine, broom, fish trap, and traditional soap. All these products are made using indigenous methods. They feature in medicinal preparations, traditional ceremonies and are important household commodities.

Conclusions: The products derived from oil palm tree serve as means of livelihood in the study communities and are local resources used in everyday activities of the people. The indigenous production methods observed further emphasize the role these products play in the economy of oil palm product makers and sellers. Sustainable tapping of palm wine should be encouraged in order to derive maximum benefits from oil palm tree.

Keywords: Ethnobotany, Economic Botany, African Oil Palm, Ondo State, Nigeria

\section{Correspondence}

Sakiru Morenikeji Erinoso*1, David Olaniran Aworinde ${ }^{1}$, Olasimbo Anuoluwapo Teniola ${ }^{2}$ and Samuel Omoniyi Ojo ${ }^{3}$

${ }^{1}$ Department of Biological Sciences, School of Science, Olusegun Agagu University of Science and Technology (OAUSTECH), Okitipupa, Nigeria

${ }^{2}$ Herbarium Unit, Department of Biological Sciences, School of Science, Olusegun Agagu University of Science and Technology (OAUSTECH), Okitipupa, Nigeria

${ }^{3}$ Department of Agricultural Economics and Extension, School of Agriculture, Food and Natural Resources Olusegun Agagu University of Science and Technology (OAUSTECH), Okitipupa, Nigeria

*Corresponding Author:

smerinoso2011@yahoo.com

Ethnobotany Research \& Applications 20:42 (2020) 


\section{Background}

African oil palm (Elaeis guineensis Jacq.) belongs to the family Arecaceae. It is a perennial crop that originated from Tropical rainforest of West Africa but has been naturalized in Madagascar, Sri Lanka, Central America, Indonesia, Malaysia, and West Indies (Olagunju 2008, Ukwuteno 2011). Nigeria as one of the largest producers of palm oil in West Africa contributes $7 \%$ to the world oil palm production of about 14.4 million tons (Olagunju 2008). The Nigerian oil palm belt covers twenty-four states including nine states (Abia, Akwa-lbom, Bayelsa, Cross-River, Delta, Edo, Imo, Ondo, and Rivers) in the Niger-Delta region with estimated plantation size ranging from 169,000 to 360,000 hectares (PIND 2011) and the industry employs millions of workers (Ofosu-Budu \& Sarpong 2013). The oil palm produces two types of vegetable oils (crude palm oil and palm kernel oil) which serve as raw materials for industries and a source of foreign exchange (OfosuBudu \& Sarpong 2013). Being one of the most important economic oil crops in Nigeria, its cultivation serves as a means of livelihood for many rural families, and a major index in rural and semi-urban economies. The palm fruit from which palm oil is extracted is of great value. Apart from the oil supply, palms are one of the most useful trees typically used in crafting activities such as making brooms, fish traps, and brushes (Barboza 2000).

Attempt to increase oil palm production in Nigeria led to the establishment of Nigerian Institute for Oil Palm Research (NIFOR) in 1939 with the mandate to provide research support in oil palm, raphia palm, date palm, coconut and recently Shea (lkuenobe 2010). The history of palm oil and economic development over the past few years has been disheartening. Nigeria was a leading exporter of palm oil before 1960; while export of palm produce declined from $36.4 \%$ in 1969 to $13.2 \%$ in 1974 (NOUN 2004), it increased dramatically between 1970 and 2003 and decreased further in 2004 (CBN 2007). This dwindling of output has been attributed to the discovery of crude oil in the 1950s and the effects of the civil war of 1967 - 1970 (Izah \& Ohimain 2016). Consequently, Nigeria lost her place as the largest producer to Malaysia (between 1962 and 1969) and Indonesia (Ohimain et al. 2014). Since local demands for palm oil and palm kernel oil are increasing, and Nigeria is unable to meet up with trade demands as it supplies $55 \%$ of total demands, it currently imports palm oil, to augment the deficit, from Malaysia and Indonesia (Izah \& Ohimain 2016). It is noteworthy that Malaysia obtained its first oil palm seeds from Nigeria (NOUN 2004). On demand, NIFOR (between 1999 and 2008) supplied about 26 million sprouted and improved oil palm seeds to farmers in Nigeria (lkuenobe 2010). NIFOR- improved early maturing, high yielding and Fusarium-resistant hybrid oil palm variety (Elaeis guineensis var. tenera, a cross between Elaeis guineensis var. dura and Elaeis guineensis var. pisifera) has become a choice cultivar yielding 15 25 tonnes fresh fruit bunch (FFB) and $3-5$ tonnes of palm oil per hectare (Ikuenobe 2010). Some technologies developed and promoted by NIFOR have been highlighted by Ikuenobe (2010). Unfortunately, Nigerian farmers have poorly adopted these production technologies.

No part of the oil palm is considered a waste as different cultures in Africa use the plant for various purposes (Gruca et al. 2015). In Nigeria, the plant is among the bio-resources widely used by native people in traditional medicine. For example, indigenous communities in Kogi State use the kernels of $E$. guineensis in the preparation of hair lotion and as anti-poison (Aniama et al. 2016) while the palm nuts are used as emmenagogue in Enugu State (Aiyeloja \& Bello 2016) and in divination (consulting Ifa oracle) in some Yoruba states. In Akure, Nigeria the roots and stem bark together with the oil of the plant is used in the treatment of malaria, asthma, and measles (Olusola \& Oyeleke 2015) while the decoction of the root is used to manage headache (Owoyele \& Owolabi 2014). The stem is a component in anticancer regimen (Soladoye et al. 2010). Juice from the young leaves of the plant is used to treat earache (Idu et al. 2014). The powder of dry fronds is used to treat skin infections; decoction of palm fronds is administered in the treatment of gonorrhoea while dried leaves are used to stop excessive bleeding (Idu \& Onyibe 2007). In the preparation of health remedies, traditional healers often infuse medicinal herbs in palm wine (Mbuagbaw \& Noorduyn 2012).

This study describes the ethnobotany and evaluates the contribution of oil palm and allied products to the household economy of the Ikale and Ilaje speaking people of Ondo State, Nigeria. The aim is to provide information on the indigenous uses, trade of oil palm products, livelihood strategies and the processing techniques predominant in the study areas.

\section{Materials and Methods Study areas}

The study was conducted in four (4) local government areas (Ese-Odo, Irele, Ilaje, and Okitipupa) of Ondo State, South-Western Nigeria (Figure 1) and these areas were periodically visited. The defunct Ikale Local Government was split into Okitipupa Local Government (6 $32^{\prime} 52^{\prime \prime}$ N, $4^{\circ} 41^{\prime} 56^{\prime \prime}$ E) and Irele Local Government ( $6^{\circ} 29^{\prime} 0^{\prime \prime}$ N, $4^{\circ} 52^{\prime} 0^{\prime \prime}$ E). Okitipupa LG is an Ikale speaking area sharing land borders with Ilaje Local Government to the 
south and Irele Local Government to the East. Hence, the Ikale people are found in Okitipupa and Irele LGAs of Ondo State; their language (lkale) is considered as a dialect of the Yoruba language. The
Ikales engage in agricultural businesses of maize, palm oil, vegetables, cocoyam, plantain, cassava, and timber.

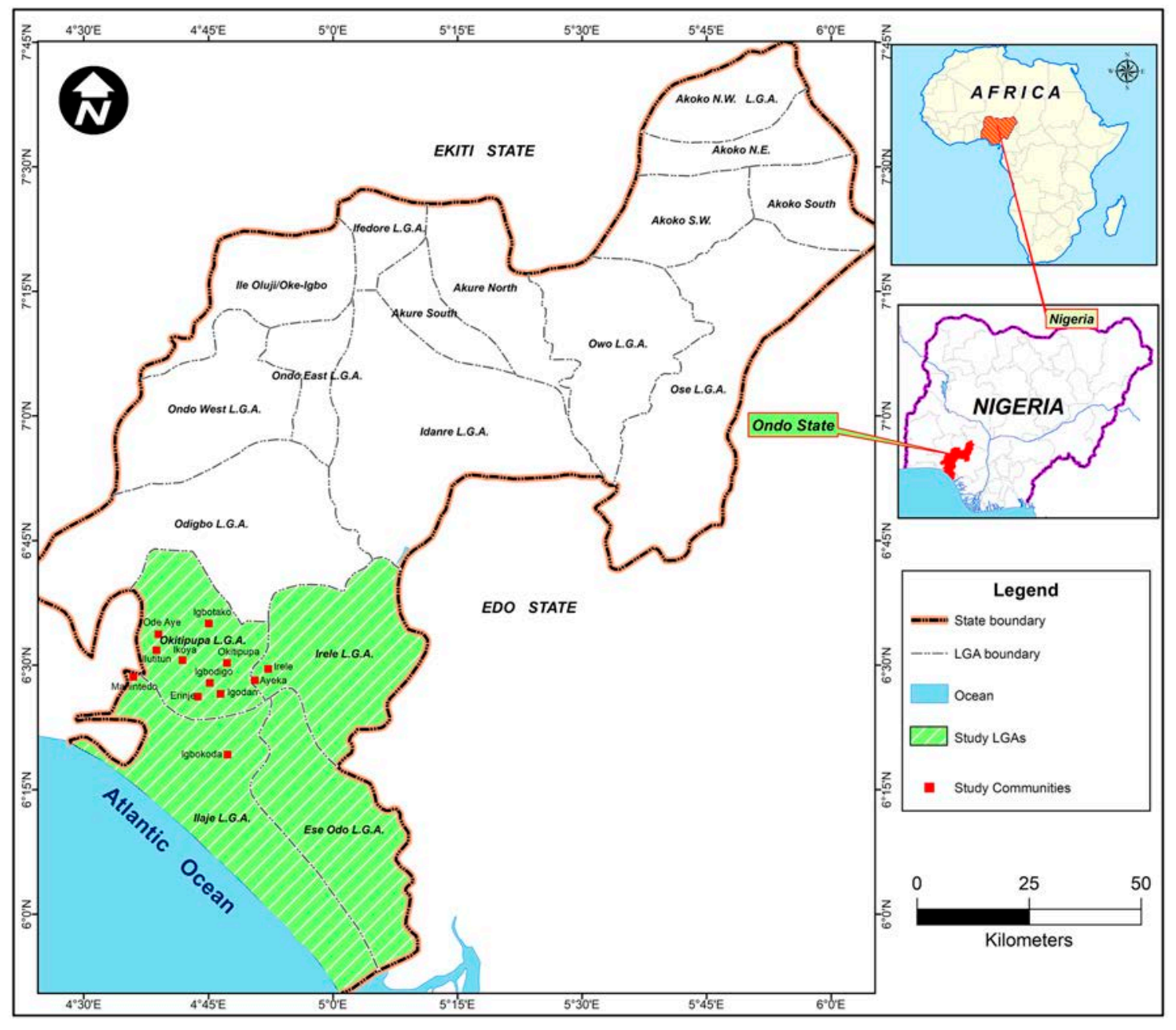

Figure 1. Map of Ondo State, Nigeria with study LGAs and communities (Map design was done using ArcGIS 10.3).

The llajes, on the other hand, are a distinct migratory coastal group residing in Ilaje Local Government $\left(6^{\circ}\right.$ $\left.12^{\prime} 11^{\prime \prime} \mathrm{N}, 4^{\circ} 46^{\prime} 4^{\prime \prime} \mathrm{E}\right)$ and also found among Apoi and Arogbo-ljaws in Ese Odo Local Government $\left(6^{\circ}\right.$ $21^{\prime} 18^{\prime \prime} \mathrm{N}, 4^{\circ} 51^{\prime} 43^{\prime \prime} \mathrm{E}$ ) as well as in Okitipupa and Irele LGAs. The llajes speak the llaje language, which is also considered to be a dialect of the Yoruba language. The occupational activities of the llajes include farming, fishing, canoe construction, fish trap making, mat making, and trading. Overall, the primary economic activity in the study areas is agriculture while the principal crops are oil palm, plantain, and cassava (processed into varied food products). Other human activities include fishing, poultry, piggery and vegetable business. Apart from the study areas having common boundaries, the Ikale and llaje people share some ethnic attributes with appreciable cultural affinities.

\section{Ethnobotanical Investigations Administration of Questionnaires}

Field trips involved the collection of palm fruits and interviews with producers and marketers of palm oil and related products. Ethnobotanical information on oil palm and its by-products was elicited from 99 respondents with the aid of structured questionnaires and personal interview (following ISE Code of Ethics 2006). Interviews were conducted in the local dialect (Ikale and Ilaje) and responses filled in the questionnaires especially for unschooled/illiterate respondents. All surveys and interviews were conducted between March 2017 and June 2018. Respondents were questioned separately to ensure reliability of information. The daily activities of the informants and their way of life were observed and carefully documented where necessary. The questionnaire was divided into two sections. Section 1 was on the demographic variables of respondents 
while section 2 evaluated the methods of collection, processing, and marketing of oil palm and its products. Informants were asked to explain the various methods used in processing as well as the tools/equipment used. The methods were recorded, and flowcharts were made accordingly. Photographs of the tools/equipment used were taken. Drawings of tools/equipment were also made on site.

\section{Data Analysis}

Data obtained from questionnaires were entered into Microsoft Excel spreadsheet (Microsoft Corporation) and analysed using simple descriptive statistics (frequency and percentages).

\section{Results and Discussion \\ Demographic Characteristics of Respondents}

Demographic variables of respondents are presented in Table 1. Ninety-nine (99) participants from four (4) local governments were sampled and interviewed. The informants were $68.7 \%$ male and $31.3 \%$ female. The age of the informants ranged from $20-70$ years. Educationally, 4 of the informants had Higher National Diploma (HND)/First degree, 6 possessed Ordinary National Diploma (OND)/Nigeria Certificate in Education (NCE), 33 had Senior School Certificate (SSC), and 42 possessed First School Leaving Certificate (FSLC) while 14 were unschooled. Eighty-nine percent $(89 \%)$ of the respondents were married, $7 \%$ single and $3 \%$ were widowed. In terms of religion, $98 \%$ were Christians while $2 \%$ practiced African Traditional Religion. Native informants numbered 61; others were non-natives. The respondents claimed that they had lived in the areas for a period between 5 and 20 years. The primary occupations of the informants were farming, trading, artisanship, and civil service.

Table 1. Demographic variables of respondents on the "importance of oil palm in the household economy of the people of Ikale and Ilaje Communities of Ondo State, Southwestern Nigeria" $(N=99)$

\begin{tabular}{|c|c|c|}
\hline Parameter & Specification & Freq. (\%) \\
\hline \multirow[t]{4}{*}{ Local Government } & Ese-Odo & $2(2.02)$ \\
\hline & Ilaje & $25(25.25)$ \\
\hline & Irele & $4(4.04)$ \\
\hline & Okitipupa & $68(68.69)$ \\
\hline \multirow[t]{2}{*}{ Gender } & Male & $68(68.69)$ \\
\hline & Female & $31(31.31)$ \\
\hline \multirow[t]{5}{*}{ Age (years) } & $>20 \leq 30$ & $4(4.04)$ \\
\hline & $>30 \leq 40$ & $22(22.22)$ \\
\hline & $>40 \leq 50$ & $25(25.25)$ \\
\hline & $>50 \leq 60$ & $43(43.43)$ \\
\hline & $>60 \leq 70$ & $5(5.05)$ \\
\hline \multirow[t]{5}{*}{ Level of Education } & Unlettered & $14(14.14)$ \\
\hline & FSLC & $42(42.42)$ \\
\hline & SSCE & $33(33.33)$ \\
\hline & OND/NCE & $6(6.06)$ \\
\hline & HND/First Degree & $4(4.04)$ \\
\hline \multirow[t]{3}{*}{ Marital Status } & Single & $7(7.07)$ \\
\hline & Married & $89(89.90)$ \\
\hline & Widow(er) & $3(3.03)$ \\
\hline \multirow[t]{2}{*}{ Religion } & Christianity & $97(97.98)$ \\
\hline & Traditional & $2(2.02)$ \\
\hline \multirow[t]{2}{*}{ Nativity } & Native & $61(61.62)$ \\
\hline & Non-natives & $38(38.38)$ \\
\hline \multirow[t]{4}{*}{ Length of residency (years) } & $>5 \leq 10$ & $13(13.13)$ \\
\hline & $>10 \leq 15$ & $17(17.17)$ \\
\hline & $>15 \leq 20$ & $23(23.23)$ \\
\hline & $>20$ & $46(46.46)$ \\
\hline \multirow[t]{4}{*}{ Primary Occupation } & Farming & $61(61.62)$ \\
\hline & Trading & $20(20.20)$ \\
\hline & Civil Service & $4(4.04)$ \\
\hline & Artisan & $14(14.13)$ \\
\hline \multirow[t]{3}{*}{ Secondary Occupation } & Farming & $72(72.73)$ \\
\hline & Trading & $8(8.08)$ \\
\hline & Artisan & $9(9.09)$ \\
\hline
\end{tabular}




\section{Oil Palm in the Household Economy of the Informants}

Cultivation of oil palm in the study areas serves as a means of livelihood for many of the informants. Palm oil, the major product, is derived from the mesocarp of the fruits (drupes) and features in soap and ointment preparations, and as margarine in cooking. In the present study, three categories of people were identified in the processing of palm oil, viz. collectors, processors, and marketers. The first category comprised male youths while male and female workers were involved in the processing stage. Female members make the bulk of palm product marketing. The findings that males dominate the collection and processing phases and females the marketing phase is in line with reports of Ekine and Onu (2008), and Ajayi and Solomon (2010). FAO (2009) noted that women engage in palm oil processing in South-Western Nigeria. Similarly, Bassey (2016) submitted that women are involved in the commercialization of oil palm than men. However, in the business of oil palm, men have more social and economic benefits than women. The economics of palm oil processing in Ondo State has been reported by Olagunju (2008) who used profitability technique and multiple regressions to evaluate the cost and returns in palm oil processing enterprise in five towns (Irele, Okitipupa, Ese-Odo, Odigbo, Ikale) in Ondo State. This study presents the products derivable from the plant and their contribution to local economy of oil palm business owners. Our research did not consider the quantitative appraisal of processors' net returns. However, studies have shown that oil palm business is profitable (Chukwu et al. 2011, Ibitoye \& Onje 2013, Onoja 2014). Furthermore, Bassey (2016) noted that palm oil is lucrative due to its uses and demand both locally and internationally and as substitute for soybean oil.

Table 2 shows the factors that were considered in the evaluation of the importance of oil palm in the livelihood strategies of the informants. The household size of the sampled informants ranged from 2 to 8 . All the respondents had at least 2 dependants. The informants highlighted that the worth of oil palm products (per month) ranged between $\$ 20,000$ and $\$ 100,000$ but the net profit fell between $\$ 5,000$ and $\$ 50,000$. The informants noted that collection of oil palm parts is both in dry and wet seasons and cited both subsistence and income as reasons for such collection. The informants further revealed that $2-8$ hours/day is employed in oil palm production activities, and likewise in other engagements (secondary occupations). Thirteen (13) respondents informed that their oil palm plantations lay about $5 \mathrm{~km}$ from their settlements whereas 38 respondents had to move $5-10 \mathrm{~km}$ to their farms, and more than $10 \mathrm{~km}$ for 48 of the informants. Similarly, distance of oil palm plantation to production site was $\leq 5 \mathrm{~km}$ for 8 participants, 5 $10 \mathrm{~km}$ for 48 participants, and more than $10 \mathrm{~km}$ for 43 respondents. Of the sampled informants, $75.18 \%$ claimed that oil palm business contributed moderately to their monthly earnings. However, $18.2 \%$ informed that the contribution was adequate while $6 \%$ lamented low benefits from oil palm business.

\section{Tools Used In Oil Palm Business and Production Methods}

Major tools/equipment used in the processing of oil palm products are highlighted in Table 3 while Figures $2 \mathrm{~A}-\mathrm{F}$ are photographs of tools/equipment used in palm oil production processes. Notable ones include cracker, presser, digester, and cooker. Figures $3 \mathrm{~A}-\mathrm{E}$ show drawings of selected tools/machines used in the processing of palm oil. Hydraulic hand press was the predominant method of processing palm oil. With the current oil palm enterprise and crude production techniques in the study areas and other oil producing belts in Nigeria, high quality and internationally acceptable oil palm product is unrealistic. Kei et al. (1997) in their comparison of oil plantations found in Nigeria and Malaysia noted that production in Malaysia is on a large scale with modern processing methods whereas in Nigeria palm oil production is on a small scale and also characterized with manual production techniques. Oil palm plantation, a sub-sector in agricultural production, has remained in the hands of small farmers and producers. With increasing population and demand for palm oil, there is need to stress the importance of efficient methods of production and upgrading of small scale to medium and large-scale production.

\section{Production Stages of Oil Palm Products}

Figures 4-9 highlight the plant parts and flow of the stages of production/preparation of different palm products (palm oil, palm kernel oil, palm wine, broom, fish trap, and traditional soap). The traditional method of producing palm oil requires the manual harvesting of fresh fruit bunches (FFB). These are packed and slashed to remove the fruits. The fruits are fermented, and the product is filtered to remove impurities. The filtrate is then cooked and digested. The resulting solution is pressed, and the oil is stored in kegs or rubber drums. In the local production of palm kernel oil, the kernels are removed by cracking the shells and are thereafter sundried and smoked. Oils are then extracted by pressing the smoked seeds. 
Table 2. Evaluation of the role of oil palm in the household economy of the people of Ikale and Ilaje Communities of Ondo State, Southwestern Nigeria $(\mathrm{N}=99)$

\begin{tabular}{|c|c|c|}
\hline Parameter & Specification & Freq. (\%) \\
\hline \multirow[t]{5}{*}{ Household size } & $\leq 2$ & $5(5.05)$ \\
\hline & $>2 \leq 4$ & $25(25.25)$ \\
\hline & $>4 \leq 6$ & $46(46.46)$ \\
\hline & $>6 \leq 8$ & $22(22.22)$ \\
\hline & $>8$ & $1(1.01)$ \\
\hline \multirow[t]{2}{*}{ Number of dependants } & $\leq 2$ & $91(91.92)$ \\
\hline & $>2 \leq 4$ & $8(8.08)$ \\
\hline \multirow{6}{*}{$\begin{array}{l}\text { Monthly income ( }) \\
\text { (from sale of oil palm products) }\end{array}$} & $>5,000 \leq 10,000$ & $17(17.17)$ \\
\hline & $>10,000 \leq 20,000$ & $19(19.19)$ \\
\hline & $>20,000 \leq 30,000$ & $24(24.24)$ \\
\hline & $>3,000 \leq 40,000$ & $23(23.23)$ \\
\hline & $>40,000 \leq 50,000$ & $10(10.10)$ \\
\hline & $>50,000$ & $6(6.06)$ \\
\hline \multirow[t]{2}{*}{ Season of collection } & Dry & $47(47.47)$ \\
\hline & Wet & $52(52.53)$ \\
\hline \multirow[t]{2}{*}{ Reason for collection } & Subsistence & $4(4.04)$ \\
\hline & Commercial & $95(95.96)$ \\
\hline \multirow[t]{5}{*}{ Hours employed in production (per day) } & $\leq 2$ & $7(7.07)$ \\
\hline & $>2 \leq 4$ & $30(30.30)$ \\
\hline & $>4 \leq 6$ & $33(33.33)$ \\
\hline & $>6 \leq 8$ & $23(23.23)$ \\
\hline & $>8$ & $6(6.06)$ \\
\hline \multirow{4}{*}{$\begin{array}{l}\text { Hours per day } \\
\text { (other engagements) }\end{array}$} & $\leq 2$ & $75(75.76)$ \\
\hline & $>2 \leq 4$ & $15(15.15)$ \\
\hline & $>4 \leq 6$ & $8(8.08)$ \\
\hline & $>6 \leq 8$ & $1(1.01)$ \\
\hline \multirow[t]{2}{*}{ Closeness to collection site } & Yes & $17(17.17)$ \\
\hline & No & $82(82.83)$ \\
\hline \multirow[t]{3}{*}{ Distance to collection site $(\mathrm{km})$} & $\leq 5$ & $13(13.13)$ \\
\hline & $>5 \leq 10$ & $38(38.38)$ \\
\hline & $>10$ & $48(48.48)$ \\
\hline \multirow[t]{2}{*}{ Closeness to production site } & Yes & $10(10.10)$ \\
\hline & No & $89(89.90)$ \\
\hline \multirow[t]{3}{*}{ Distance to production site $(\mathrm{km})$} & $\leq 5$ & $8(8.08)$ \\
\hline & $>5 \leq 10$ & $48(48.48)$ \\
\hline & $>10$ & $43(43.43)$ \\
\hline \multirow[t]{3}{*}{ Contribution of oil palm to monthly earning } & Low & $6(6.06)$ \\
\hline & Moderate & $75(75.76)$ \\
\hline & Adequate & $18(18.18)$ \\
\hline
\end{tabular}

Table 3. Oil palm products and required tools/equipment

\begin{tabular}{|l|l|}
\hline Oil palm product & Tools/Equipment \\
\hline Palm oil & $\begin{array}{l}\text { Lister engine, digester, presser, cooker, thresher, sieve, axe, shovel, } \\
\text { harvester, wheelbarrow, drum, washer }\end{array}$ \\
\hline Palm kernel oil and kernel shells & $\begin{array}{l}\text { Lister engine, head pan, shovel, cracker, digester, filter, drums, } \\
\text { wheelbarrow, presser }\end{array}$ \\
\hline Palm wine & Climbing rope, cutlass/tapping knife, keg/calabash, filter \\
\hline Broom & Cutlass, knife \\
\hline Fish trap & Cutlass, knife \\
\hline Traditional soap & Cooker, head pan, wheelbarrow, shovel, burner \\
\hline
\end{tabular}

Source: Field Survey $(2017-2018)$. 

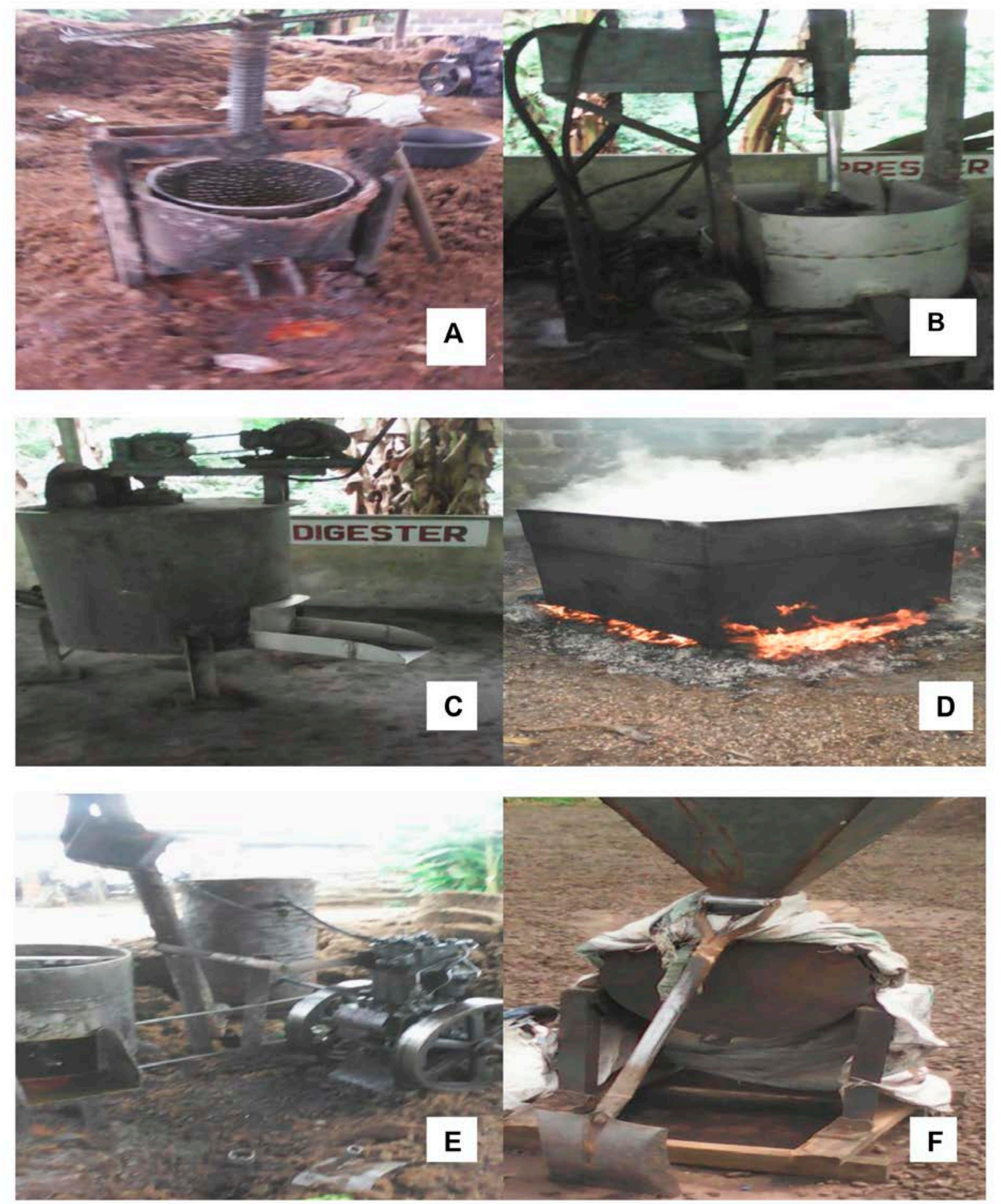

Figure 2. Equipment/machines used in the processing of palm oil. A: Manual hydraulic presser; B: Electric presser; C: Digester; D: Boiling trough; E: Lister engine, F; Cracker/Grinder. 

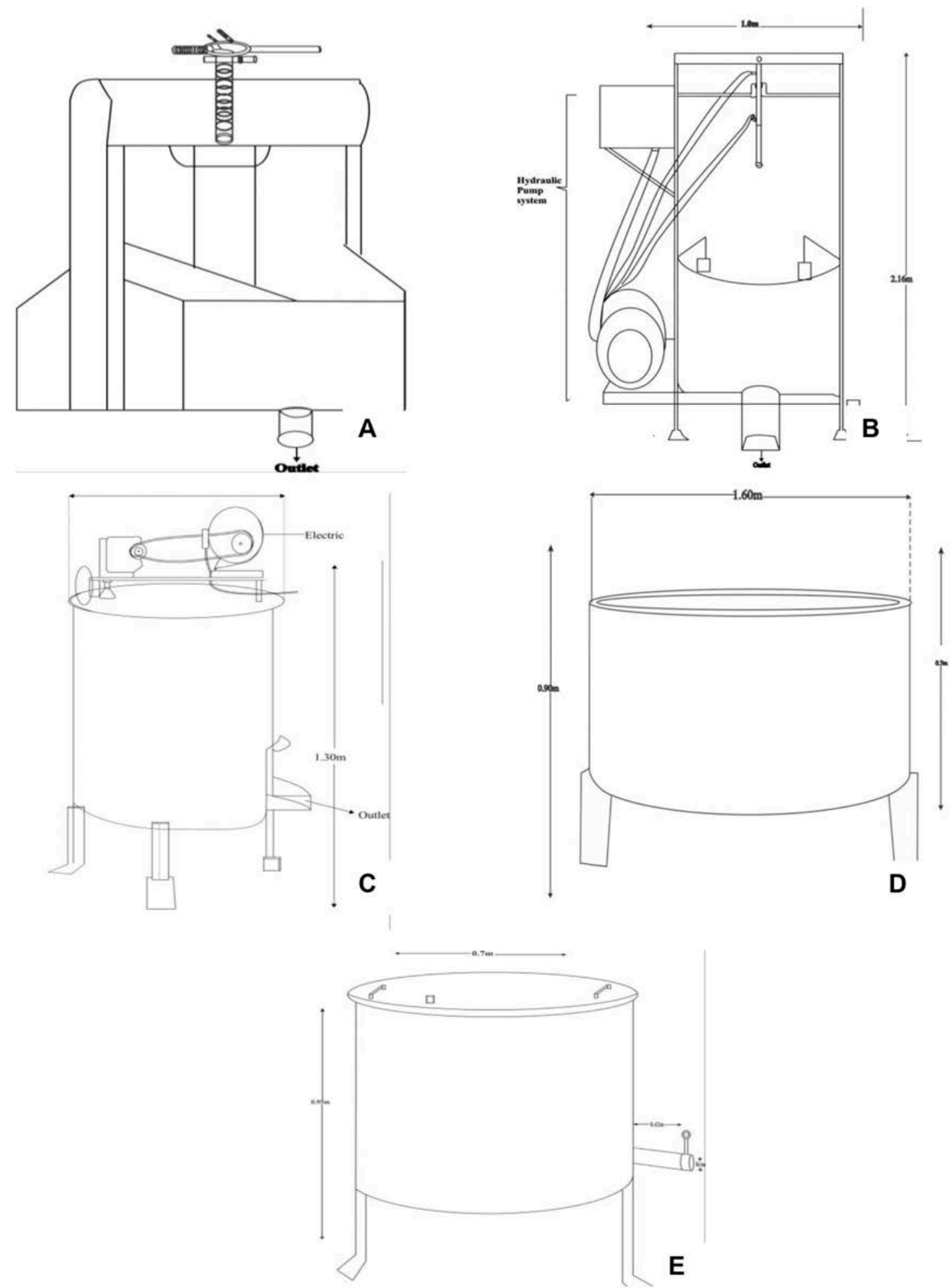

Figures 3. A-E: Drawings of selected tools/machines used in the processing of palm oil. 


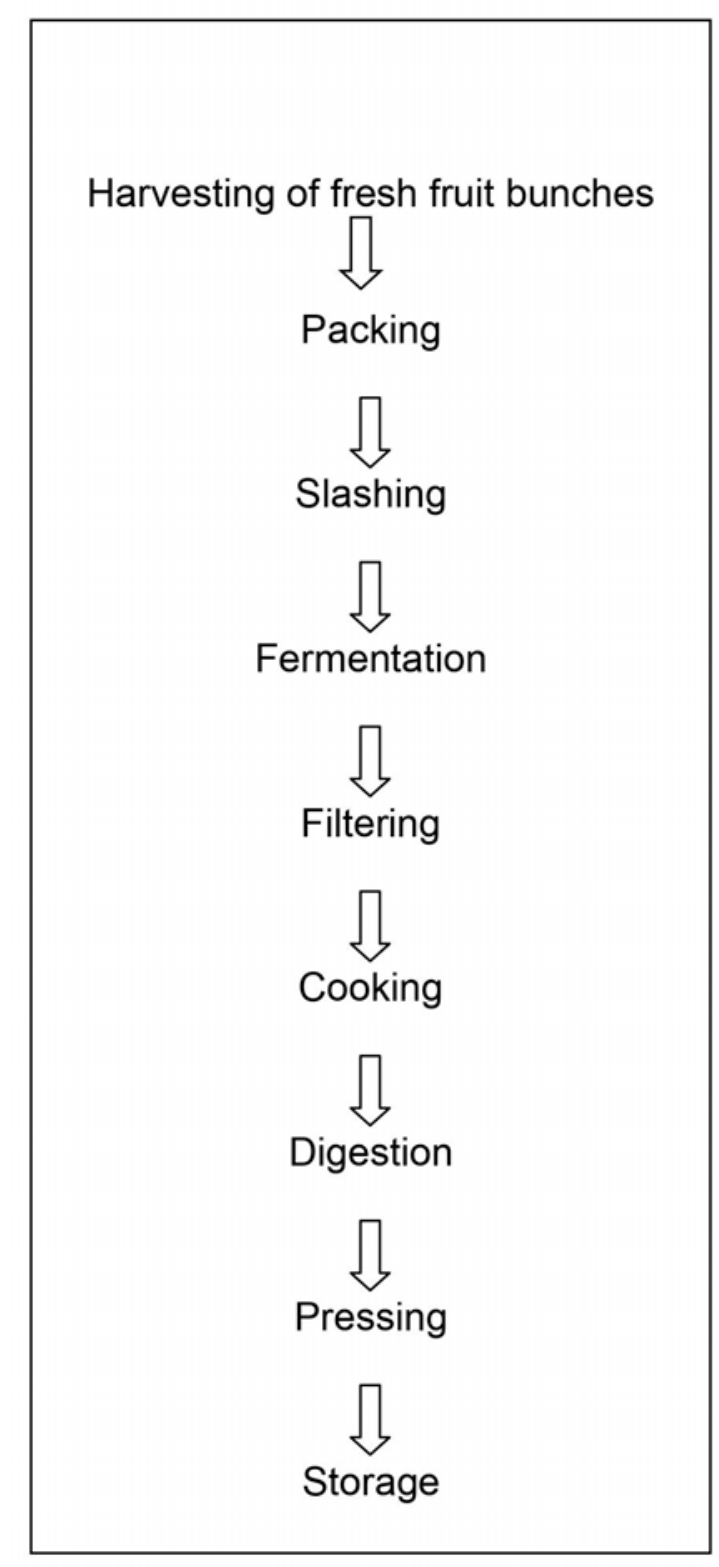

Figure 4. Flowchart for the traditional preparation of palm oil

Palm wine tappers climb to the top of the palm tree (using climbing rope), prune the tree with cutlass, perforate the stem by the side or middle with tapping knife, and fasten a keg/calabash container to obtain the sap. The wine is later stored in big kegs/drums for personal consumption or sale. Tappers also use a destructive method which requires the cutting down of palm trees before the process of tapping begins. Felled palm trees are pruned by removing the fronds and inflorescences. They are perforated and the sap allowed drip into a keg placed at the hole made. This method is not sustainable as palm trees tapped in this way later become useless. In the making of broom, collectors cut down palm fronds and trim the leaflets to derive the rachis or mid-rib. The trimmed axis (still green) may be collated and packaged for use or sale. In another way, the strips are dried (become brown), selected, packaged and tightened using a fiber rope or elastic rubber ribbon. The dried (brown) strips are more commonly made for sale than the undried (green) broom.

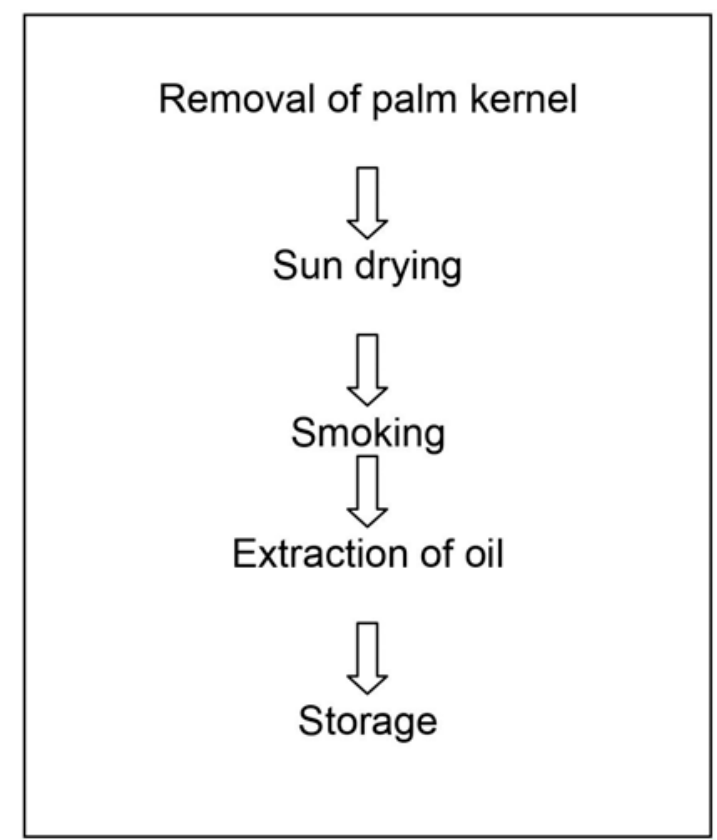

Figure 5. Flowchart for the making of palm kernel oil

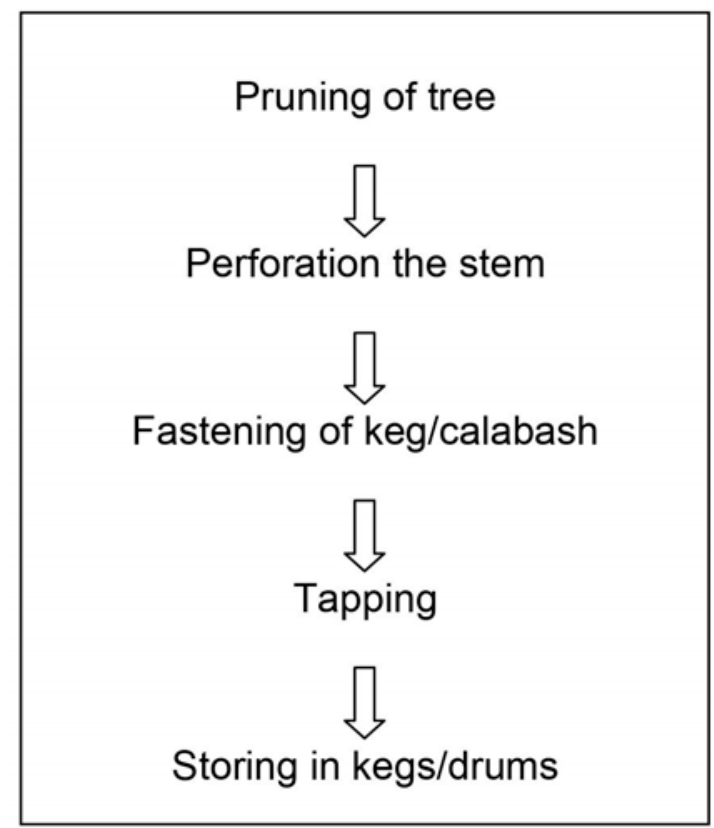

Figure 6. Flowchart for the tapping of palm wine

Fish trap weavers harvest palm fronds with petioles. The leaf stalks are removed, dried, and dressed. These are carefully woven into a cylindrical fish trap implement. To prepare local soap, palm kernel shells are charred (alkali base) and sieved. The ashes are cooked after being mixed with thick palm oil (lkete). The suspension is allowed to cool, and the 
precipitate is later moulded into balls; these balls are stored for some days. They are later pressed and cooked again. The resulting product is further allowed to cool and then finally stored.

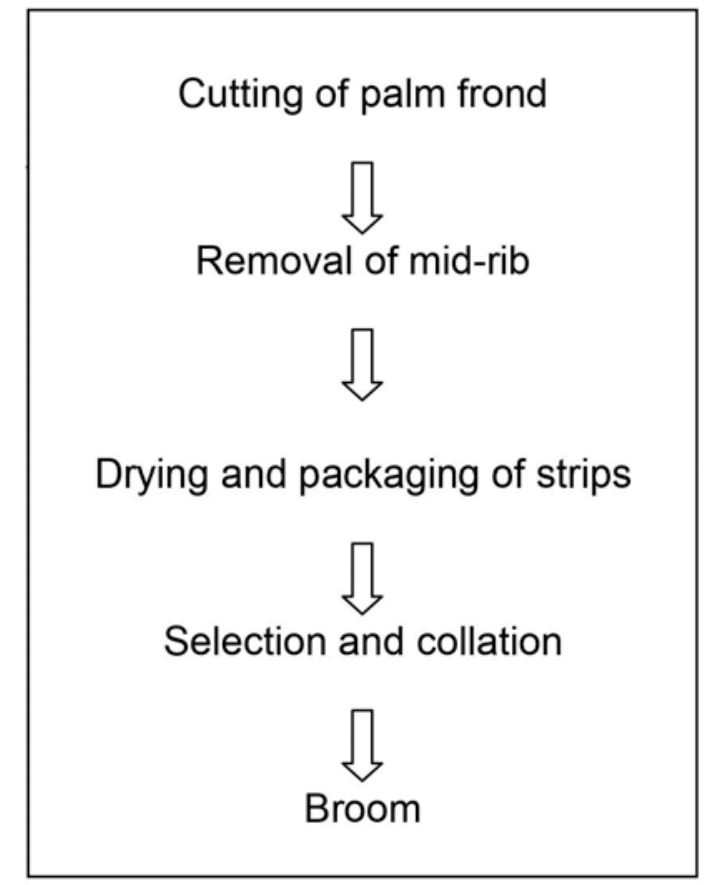

Figure 7. Flowchart for the making of broom

Harvesting of frond with petiole

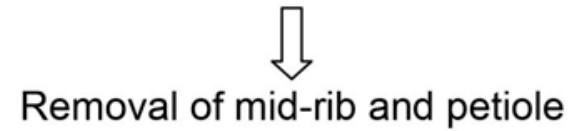<smiles>[C]1C=CC=C1</smiles>

\section{Drying and Dressing}<smiles>CC=C/C=C\C</smiles>

Fish trap

Figure 8. Flowchart for the making of fish trap

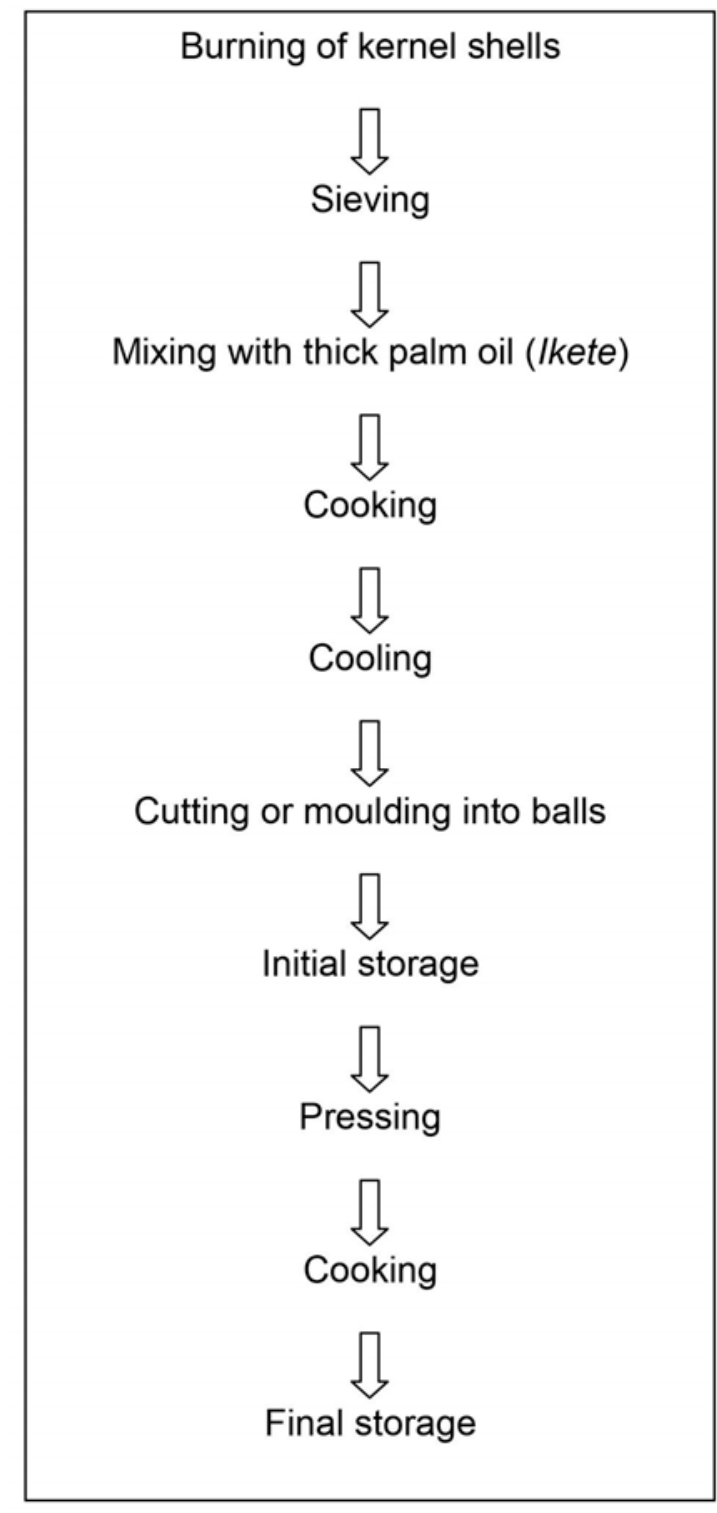

Figure 9. Flowchart for the making of traditional soap

\section{Oil Palm Products}

Figures 10A-F show a manual worker removing palm fruits from fresh fruit bunch, container for holding fruits, palm kernels, palm fibers, kernel waste, and palm fronds used as thatch for roofing a palm wine shop while Figures $11 \mathrm{~A}-\mathrm{H}$ are products that can be derived from different parts of oil palm. There is a general belief that all parts of palm tree are useful. In the study areas, the plant is the principal source of palm oil. Other products that are derived from oil palm parts are kernel meat (processed into livestock feed), palm kernel oil, palm wine, palm frond (for thatch), kernel shells for fuel, traditional soap and other products such as broom, fish trap and scarred stem (as bridge in some rural areas). The report of Reddy et al. (2019) is in agreement with some of the uses of oil palm tree observed in this study. Besides the social benefits (employment and income) of red palm oil and palm 
kernel oil production, the nutritional values of these oils have been assessed and also compared with other oil sources (Nagendran et al. 2000, Atasie \&
Akinhanmi 2009, Adetuyi et al. 2014, Mancini et al. 2015).
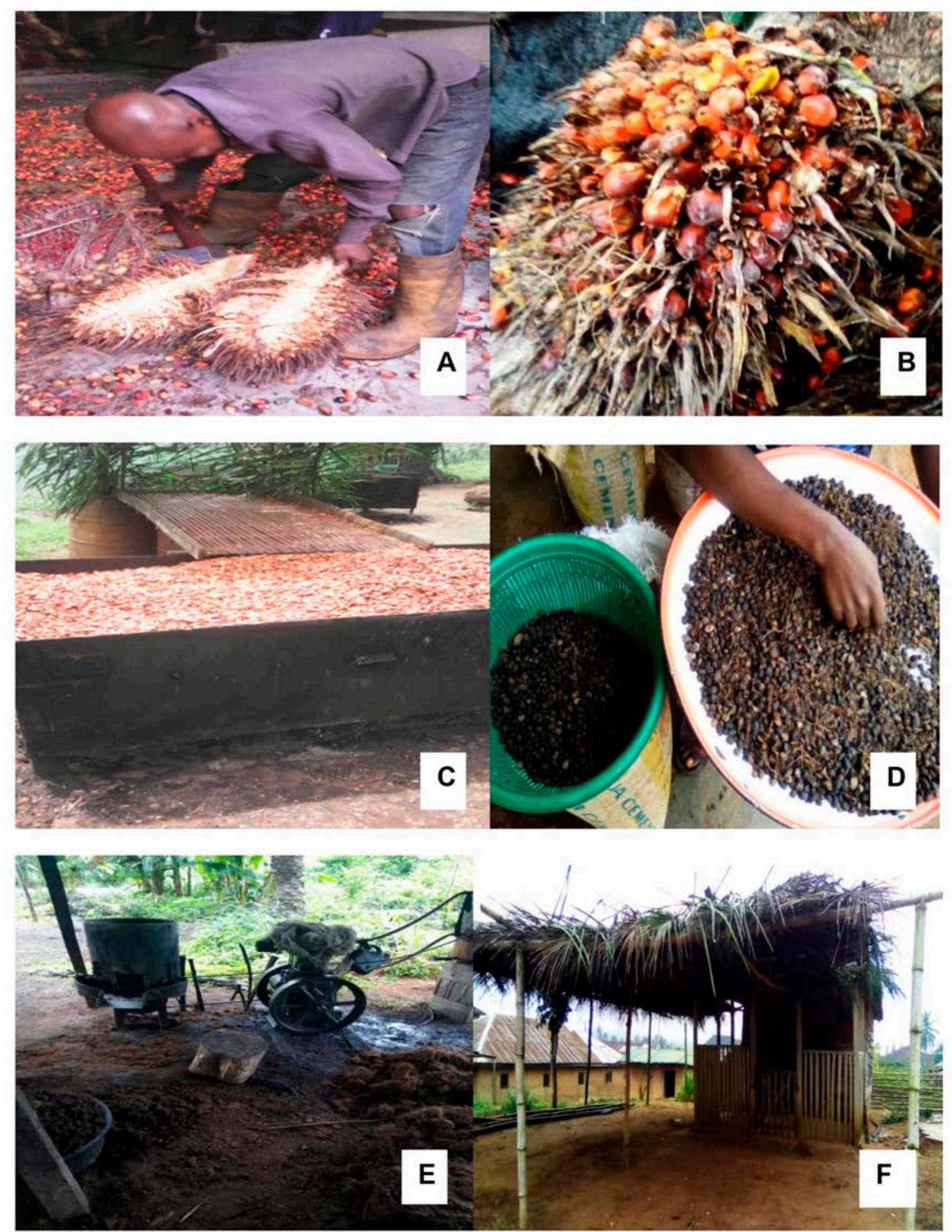

Figure 10. A: Manual worker slashing palm fruit bunch; B: Oil palm fruits from fresh fruit bunch; C: Trough for holding fruits; D: Palm nuts and kernels; E: Palm fibers and bunch waste at production site; F: Palm fronds used as thatch for roofing a palm wine shop (under construction) 

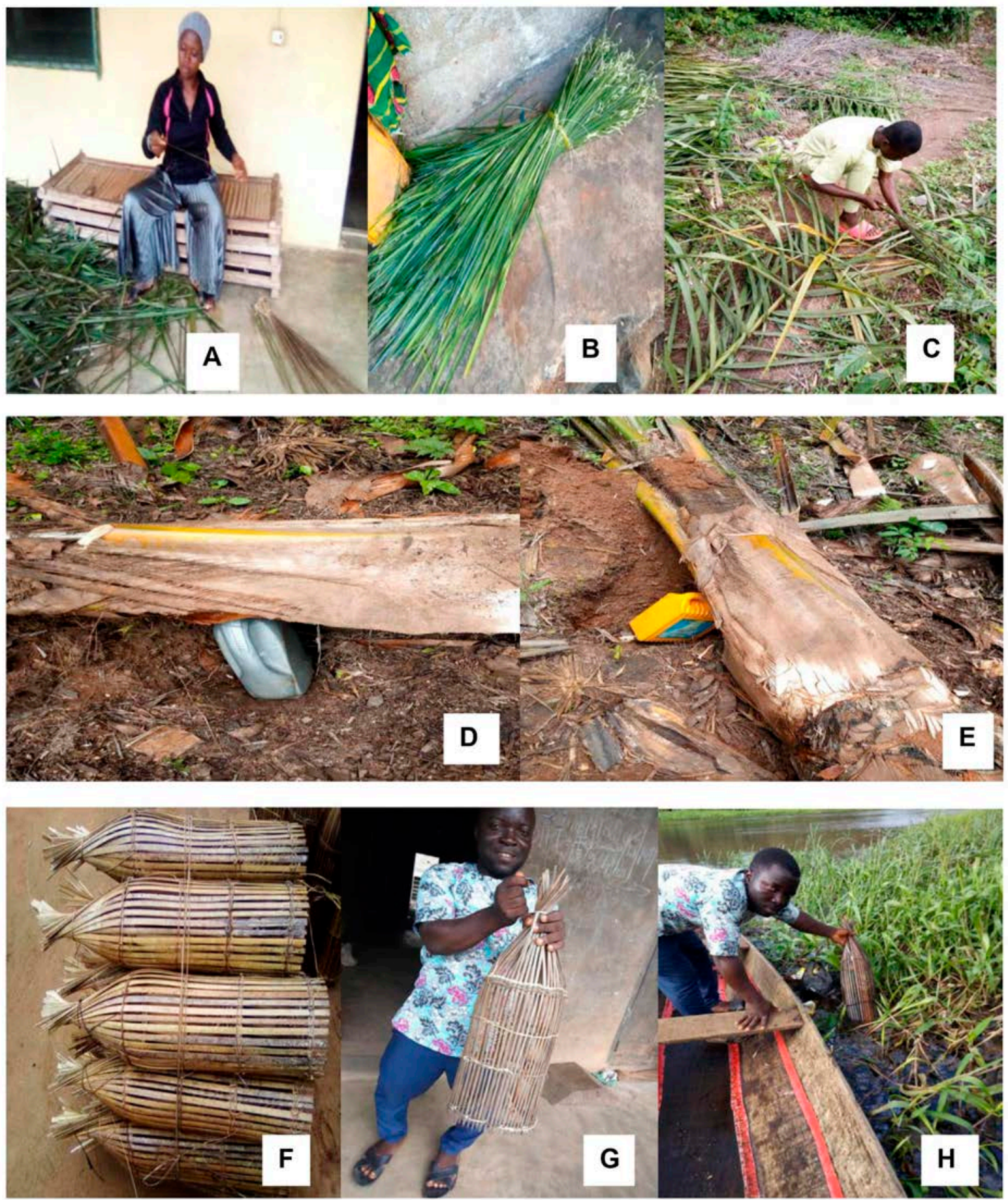

Figure 11. Products derivable from different parts of oil palm. A-C: Palm fronds and the making of broom. D \& E: Tapping of palm wine. F-H: Fish trap made from palm petiole and palm frond mid-rib.

The importance of carotene-rich red palm oil cannot be over-emphasized. The oil finds application is everyday culinary art. Besides the cooking uses, among the Ikale and llaje speaking people, palm oil is used as an antidote for poisoning in infants, as pain reliever, and as first aid in convulsing infants/teenagers. The oil is also used to ripen and soften boil, and together with sugar in the treatment of mild cough. It is also a component in many medicinal preparations (for skin diseases, whitlow, and as ointment for wounds). Gruca et al. (2014) have reported the ritual uses of palm oil. The oil (together with coconut fruit) is used to prevent miscarriage among the Yorubas in Nigeria. A preparation of Shea butter and palm oil, and ritual recitation of some words is considered effective in treating malaria.

Palm kernel oil produced in the study areas is consumed and sold in markets (Ayeka, Okitipupa, 
Irele and Igbokoda) close to the study communities. Kernel shells are used to fill eroded routes leading to the processing sites in the study areas. Shells and chaff are also used as fuel materials during boiling and sterilization. Atasie and Akinhanmi (2009) reported the indigenous uses of kernel oil as local body creams, medicines and dressings of minor wounds. The oil is also used industrially as vegetable oil and in soap production (Ekpa 1995). On a grand scale, palm kernel residues are viable materials in biofuel production (Ayetor et al. 2015).

Palm wine is a beverage obtained by natural fermentation of the sap of various types of palm trees. This indigenous wine can be obtained from $E$. guineensis (this study) and some Raphia spp. and is regarded as a refreshing beverage served as a drink during kingship, marriage and naming ceremonies in some parts of Nigeria. In the study areas, palm wine is used to treat malaria. It is served as a drink and used to bath in the management of jaundice and measles. The wine is also used to promote lactation, treat conjunctivitis, and improve eyesight (Mbuagbaw \& Noorduyn 2012). Palm wine not only serves as source of revenue but also as source of medicinal, alcoholic, and sugary materials (Ikegwu 2014). Palm wine tapping is common in many palmgrowing regions and is a major occupational engagement among rural folks in Nigeria (Obahiagbon 2009). Traditional methods of tapping have been reported by lkegwu (2014) and Mba et al. (2019). A destructive and unsustainable method of tapping was observed in the study areas.

Brooms are household items that have been used for centuries to clean houses, yards, gardens, roadsides, and streets; some brooms are also used to collect grain during threshing (Nedelcheva et al. 2007). They are domestically produced and handmade from tree branches, shrubs and palms. Broom making is a local business that creates jobs for families and communities (Barboza 2000). Being a utility item, the production contributed to the livelihood means and economy of the people in the study areas.

Natural materials are used in the construction of traditional fishery and fishing-related tools and equipment (Savo et al. 2013). Studies on the uses of plants in traditional fishery are scarce and fragmentary (Peroni et al. 2008). However, the use of Cocos nucifera and splits from Bambusa vulgaris in traditional fish trapping devices has been reported (Baruah et al. 2013, Savo et al. 2013). On the other hand, durable traps or nets made from synthetic materials are common.
Soap is a commodity that is in high demand because of its usefulness in general cleaning. In this study, the ashes of the palm kernel shells serve as the alkali base for the local production of soap while the thick palm oil (lkete) is the fat and oil component. Irvine (1965) noted that many agricultural wastes (palm bunch waste, kolanut pods, cocoa pods, maize cob etc.) when burnt give ashes that are rich in potassium and sodium. Osagie and Enyi (2015) found that soaps produced from agricultural wastes could compete favourably with any standard soap. Ogunsuyi and Akinnawo (2012) compared the quality and chemical characteristics of black soap (obtained from palm bunch ash-derived alkali and coconut oil through traditional and improved methods) and synthetic alkali soap. The authors concluded that high demands and cost of synthetically produced soaps could be reduced by exploring vegetable matter in local soap production. Apart from this benefit, the recovery and conversion of agricultural wastes will also sustain our environment and reduce land and water pollution.

\section{Challenges and Future Prospects of Oil Palm Business}

Respondents listed scarcity of harvester, difficulty during harvest, price fluctuation, weather constraints, poor road network, theft, poor attitude of laborers to work, high cost of equipment maintenance, and low patronage (for fish trap) as challenges they are facing in the oil palm business. All the informants agreed that for an improvement in local livelihoods to occur oil palm plantations must be expanded by acquiring more land space for farming, and viable seedlings must be procured. In addition, mechanization of production processes, provision of social amenities (water, electricity, hospitals etc.) and provision of credit facilities to upgrade small scale farming to medium/large scale are necessary. Price regulation, tax reduction, provision of aids and support in form of loans, grants, equipment, improvement of road network (especially where collection sites are far from processing sites), and product promotion to increase patronage fall in the government's domain. Individuals and governments need to identify the areas of need and support. Private-Public Partnerships (PPP) should be encouraged.

\section{Conclusions}

This study has reported the ethnobotanical uses of products derivable from Elaeis guineensis and its contribution to the livelihood strategies of the Ikale and Ilaje speaking people of Ondo State, Nigeria. Oil palm products play important roles in everyday activities of the people. These products find application in many medicinal preparations, traditional ceremonies, and as household items. In 
the study communities, palm oil production is characterized by crude processing methods. We believe that the equipment/tools used in the processing of various products from the plant could be improved or modernized to enhance production, product appeal, and income. In addition, small-scale oil palm processors should be encouraged to use improved planting materials and acquire the integrated small-scale processing equipment developed by NIFOR. Government should also provide credit facilities in the form of investment funds to step up production as inefficient processing methods result to loss of considerable palm oil products. Efforts should be geared towards the sustainable use of palm resources.

\section{Declarations}

List of Abbreviations: HND: Higher National Diploma; OND: Ordinary National Diploma; NCE: Nigeria Certificate in Education; SSC: Senior School Certificate; FSLC: First School Leaving Certificate; ISE: International Society of Ethnobiology; FAO: Food and Agricultural Organization; NOUN: National Open University of Nigeria; CBN: Central Bank of Nigeria; NIFOR: Nigeria Institute for Oil Palm Research; FFB: Fresh Fruit Bunches

Ethics Approval and Consent to Participate: All informants gave their consent prior to the commencement of the study after they were duly informed.

Consent for Publication: The informants agreed that the photographs of the tools/equipment and that of the manual workers and processors could be published.

Availability of Data and Materials: Datasets were not deposited in public repositories.

Competing Interests: Authors declare no competing interests of any kind.

Funding: Authors received no funds/grants for this study.

Authors Contributions: SME and DOA conceived and designed the study. All authors (SME, DOA, OAT and SOO) were involved in data collection (questionnaire administration and interviews). SME did the data analysis and wrote the first draft of the manuscript. DOA reviewed and edited the first draft. All authors approved the final draft.

\section{Acknowledgements}

Many thanks are due to all the respondents for the consent to carry out the research and the time they spared for questions and interviews and the permission to take photographs of their tools. We are also grateful to Ms. Adebimpe Akinniyi (Registry, OAUSTECH) for the drawings and technical assistance. We would like to thank the reviewers for useful suggestions which have greatly improved the manuscript.

\section{Literature Cited}

Adetuyi OO, Aladekoyi G, Akinbobola AP, Adedokun BC. 2014. Comparative study of proximate composition of oil extracted from African catfish viscera (Clarias gariepinus) and red palm oil. Journal of Fisheries and Aquatic Science 9(5): 372-376.

Aiyeloja AA, Bello OA. 2006. Ethnobotanical potentials of common herbs in Nigeria. A case study of Enugu State. Educational Research and Review 1:16-22.

Ajayi MT, Solomon O. 2010. Influence of extension contact and farmers' socio-economic characteristics on adoption of oil palm technologies in Aniocha North Local Government, Delta State. JAGST 12(2): 35-46.

Aniama SO, Usman SS, Ayodele SM. 2016. Ethnobotanical documentation of some plants among Igala people of Kogi State. The International Journal of Engineering and Science 5: 33-42.

Atasie VN, Akinhanmi TF. 2009. Extraction, compositional studies and physico-chemical characteristics of palm kernel oil. Pakistan Journal of Nutrition 8(6): 800-803.

Ayetor GK, Sunnu A, Parbey J. 2015. Effect of biodiesel production parameters on viscosity and yield of methyl esters: Jatropha curcas, Elaeis guineensis and Cocos nucifera. Alexandria Engineering Journal 54(4): 1285-1290.

Barboza NM. 2000. Broom making from palms in Cuba. Palms 44(2): 59-62.

Baruah D, Dutta A, Pravin P. 2013. Traditional fish trapping devices in the Brahmaputra valley of Assam. Indian Journal of Traditional Knowledge 12(1): 123-129.

Bassey OI. 2016. Overview of oil palm production in Nigeria: comparative social and environmental impacts - the case of Ekong Anaku Community in Cross River State, Nigeria. Institute of Social Sciences, Erasmus University of Rotterdam 15(3): 110.

Central Bank of Nigeria (CBN). 2007. Statistical Bulletin, CBN, Abuja, Nigeria.

Chukwu AO, Onweagba AE, Nwosu CS, Osondu PC. 2011. Economic assessment of palm oil processing in Owerri Agricultural Zone of Imo State. International Journal of Agriculture and Rural Development 14(2): 703-706.

Ekine DI, Onu ME. 2008. Economics of small scale palm oil processing in Ikwerre and Etche Local Government Areas of River State, Nigeria. Journal of Agriculture and Social Research 8(2): 1-9.

Ekpa OD. 1995. Bio-inorganic constituents and possible uses of the female inflorescence of oil palm. 
West African Journal of Biology and Applied Chemistry 40: 13-18.

Food and Agricultural Organization (FAO). 2009. The major significance of "minor forest products". Available

at: http://www.fao.org/docrep/T9450E/t9450e00.HTM.

Rome, Italy.

Gruca M, van Andel TR, Balslev H. 2014. Ritual uses of palms in traditional medicine in sub-Saharan Africa: a review. Journal of Ethnobiology and Ethnomedicine 10:60

Ibitoye SJ, Onje SO. 2013. Economic analysis of oil palm fruit processing in Dekina Local Government Area of Kogi State, Nigeria. Academia Arena 5(11): 65-73.

Idu M, Erhabor JO, Ovuakporie-Uvo O. 2014. Ethnomedicinal plants used by the Idoma people, Benue State, Nigeria. American Journal of Ethnomedicine 1: 72-88.

Idu M, Onyibe HI. 2007. Medicinal plants of Edo State, Nigeria. Research Journal of Medicinal Plants 1: $32-41$

Ikegwu JU. 2014. The value of palm wine tapping in the food production practices of Igboland. A case study of Idemili South Local Government Area, Anambra State. Research on Humanities and Social Sciences 4(6): 49-54.

Ikuenobe CE. 2010. Stimulating real sector output through research and development: The Nigerian Institute for Oil Palm Research (NIFOR) Experience. Economic and Financial Review, Central Bank of Nigeria 149-163.

International Society of Ethnobiology (ISE). 2006. ISE Code of Ethics (with 2008 additions). Available at: http://Ethnobiology.net/code-of-ethics/

Irvine FR. 1965. West African Crops (3rd Edition). Oxford University Press. pp. 97-114.

Izah SC, Ohimain EI. 2016. The opportunities and weakness of Nigerian oil palm industry. Biotechnological Research 2(1): 33-43.

Kei K, Mywish M, Duncan B. 1997. Transformation versus stagnation in the oil palm industry: A comparison between Malaysia and Nigeria. Staff Paper 97-5. Department of Agricultural Economics, Michigan State University, East Lansing, Michigan.

Mancini A, Imperlini E, Nigro E, Montagnese C, Daniele A, Stefania O, Buono P. 2015. Biological and nutritional properties of palm oil and palmitic acid: Effects on health. Molecules 20: 17339-17361.

Mba EH, Ekpo AS, Ozim EC, Oladeinde SO. 2019. Assessment of traditional palm wine tapping practice: effect on vegetation in Nasarawa State, Nigeria. International Journal of Environment and Climate Change 9(12): 841-851.
Mbuagbaw L, Noorduyn S. 2012. The palm wine trade: occupational and health hazards. The International Journal of Occupational and Environmental Medicine 3: 157-164.

Nagendran B, Unnithan UR, Choo YM, Sundram K. 2000. Characteristics of red palm oil, a carotene- and vitamin E-rich refined oil for food uses. Food and Nutrition Bulletin 21(2): 189-194.

National Open University of Nigeria (NOUN). 2004. Export Crop Agriculture. In: Geography of Nigeria. Heinemann Educational Books, Lagos, Nigeria.

Nedelcheva AM, Dogan Y, Guarrera PM. 2007. Plants traditionally used to make brooms in several European countries. Journal of Ethnobiology and Ethnomedicine 3(20): 1-11.

Obahiagbon FI. 2009. A review of the origin, morphology, cultivation, economic products, health and physiological implications of Raphia palm. African Journal of Food Science 3(13): 447-453.

Ofosu-Budu K, Sarpong D. 2013. Oil palm industry growth in Africa. A value chain and small holders study for Ghana. 349-350 in Rebuilding West Africa's food potential, Edited by A. Elbehri. FAO/IFAD.

Ogunsuyi HO, Akinnawo CA. 2012. Quality assessment of soaps produced from palm bunch ash-derived alkali and coconut oil. Journal of Applied Science and Environmental Management 16(4):363366.

Ohimain El, Emeti Cl, Izah SC, Eretinghe DA. 2014. Small-scale palm oil business in Nigeria: A feasibility study. Greener Journal of Business and Management Studies 4(3): 70-82.

Olagunju FI. 2008. Economics of palm oil processing in Southwestern Nigeria. International Journal of Agricultural Economics and Rural Development 1(2): 69-77.

Olusola JA, Oyeleke OO. 2015. Survey and documentation of medicinal plants in wildlife park of Federal University of Technology, Akure, Nigeria. International Journal of Life Sciences Research 3: 238-246.

Onoja AO. 2014. Economic survey of oil palm products' processing and marketing in Kogi State, Nigeria. Consilience: The Journal of Sustainable Agriculture 13(1); 336-346.

Osagie OF, Enyi CC. 2015. Utilization of agricultural waste (rubber, seed oil, kolanut pods and almond leaves) for soap production. IIARD International Journal of Geography and Environmental Management 1(8): 121-135.

Owoyele BV, Owolabi GO. 2014. Traditional oil palm (Elaeis guineensis Jacq.) and its medicinal uses. A Review. TANG Humanitas Medicine 4. e16.

Peroni N, Begossi A, Hanazaki N. 2008. Artisanal fishers' ethnobotany: from plants diversity use to 
agro-biodiversity management. Environment, Development and Sustainability 10(5): 623-637.

PIND 2011. A report on palm oil value chain analysis in the Niger Delta. Foundation for Partnership Initiatives in the Niger Delta (PIND), Abuja, Nigeria. 69pp.

Reddy MT, Kalpana M, Swaraj N, Kamala V, Pandravada SR, Sunil N. 2019. Indigenous traditional knowledge on health and equitable benefits of oil palm (Elaeis spp.). Open Access Library Journal 6: e5103.

Savo V, La Rocca A, Caneva G, Raphallo F, Cornara L. 2013. Plants used in artisanal fisheries on the Western Mediterranean coasts of Italy. Journal of Ethnobiology and Ethnomedicine 9(9): 1-14.

Soladoye MO, Amusa NA, Raji-Esan SO, Chukwuma EC, Taiwo AA. 2010. Ethnobotanical survey of anti-cancer plants in Ogun State, Nigeria. Annals of Biological Research 1: 261-273.

Ukwuteno SO. 2011. Economics of small-scale oil palm production in Kogi State, Nigeria. Unpublished PhD thesis, Department of Agricultural Economics, Faculty of Agriculture, University of Nigeria, Nsukka. $150 \mathrm{pp}$ 